\title{
Potřebujeme kvalitní nebo kvalifikované učitele?
}

\author{
Vladimíra Spilková, Radka Wildová \\ Univerzita Karlova v Praze, Pedagogická fakulta
}

Touto provokativní otázkou byl uveden Kulatý stůl SKAV a EDUIN ${ }^{1}$ v rámci veřejné diskuze, která se rozvinula kolem řešení aktuálního problému souvisejícího s ukončením desetiletého období výjimky ze zákonem stanovených požadavků na kvalifikaci učitelů. Po letech nečinnosti a nezájmu vzdělávací politiky se tak otázky kvality a kvalifikovanosti učitelů, jejich př́pravy i dalšího profesního rozvoje dostávají do centra pozornosti. Skutečnost, že v českém školství dlouhodobě působí značné procento nekvalifikovaných učitelů, a že na základních školách dokonce učí nezanedbatelné množství maturantů, byla všeobecně známá. Tato časovaná bomba nechávala až do letošního roku státní správu v relativním klidu.

Analytická zpráva z mimořádného šetření o nekvalifikovaných pedagogických pracovních, $\mathrm{v}$ níž jsou podrobně uvedeny výsledky šetření realizovaného v únoru 2014, přináší údaje o celkovém počtu 11090 učitelů bez odborné kvalifikace pro přímou pedagogickou činnost, tj. 8,2 \%. Po přepočtení na plné úvazky se jedná o 8380 učitelů, tj. 6,4\%. Největší počet nekvalifikovaných učitelů je na středních školách (téměř 5400 učitelů, po přepočtení na plné úvazky 4500 učitelů), dále na 1. stupni ZŠ téměř 5100 (3 300 - plné úvazky), na 2. stupni ZŠ zhruba 4300 (3000 - plné úvazky), v mateřských školách 3500 (téměř 3000 - plné úvazky). Předmětem zkoumání nebyly prríčiny současného počtu učitelů bez odborné kvalifikace (např̀ jaký podíl na něm má neochota stávajících učitelů doplnit si formální vzdělání, nesoulad mezi poptávkou nekvalifikovaných učitelů a nabídkou studijních programů vysokých škol).

Naléhavost problému vyprovokovala zájem širší veřejnosti, učitelů, rodičů, profesních asociací, odborů, který byl podporován výraznou mediální kampaní. ${ }^{2} \mathrm{~V}$ rámci rozsáhlých internetových diskuzí byli oslovováni představitelé

1 Kulatý stůl se konal 20. února 2014. Podrobnější informace na www.skav.cz a www.eduin.cz.

2 Způsob medializace byl problematický, místy manipulativní, nezř́́dka byly podsouvány subjektivní názory několika jednotlivcủ jako většinové názory a široce sdílené zkušenosti. Konkrétně např. výroky typu „většina učitelů z praxe studuje na VŠ jen kvůli papíru, nepředpokládají, že by se tam dozvěděli něco, co neznají z praxe nebo kurzů“. Demagogické bylo např zdůrazňování protikladu učitele nekvalifikovaného, ale kvalitního a zaujatého versus kvalifikovaného, ale nemotivovaného, nevzdělávajícího se atd. Obhajovat nekvalifikované učitele dehonestací kvalifikovaných je přinejmenším nefér. Za zmínku stojí, že značná část kritických hlasů směrem $\mathrm{k}$ formálnímu vzdělávání učitelů zaznívala od lidí, kteří ho neabsolvovali, tedy s ním neměli vlastní zkušenost.

DOI: $10.5817 /$ PedOr2014-3-423 
různých profesních komunit, aby se vyjádřili k cíleným otázkám, např.: Proč je tak důležité formální vzdělání učitelů? Jak se liší po několikaleté praxi učitel bez diplomu a s diplomem? Je správné/nutné, aby nekvalifikovaní učitelé museli odejít ze škol, respektive si povinně doplnit vzdělání? Co nového se dozvědí učitelé s praxí na pedagogické fakultě? Co nám brání kromě zákona v tom, abychom uznali praxi zkušeným učitelům? Je třeba nějak zásadně proměnit naše vysoké pedagogické školy?

Autorky tohoto příspěvku byly osloveny redakcí Literárních novin, aby v rámci strukturovaného diskuzního fóra odpověděly na vybrané otázky a poté byly vyzvány k napsání ucelenějšího textu, který by formuloval argumenty vysvětlující a obhajující požadavek na kvalifikaci učitelů v podobě vysokoškolského studia učitelství. Mediální bouře po několika měsících ustala, ve veřejném prostoru však zůstalo mnoho nezodpovězených zásadních otázek, znepokojivých a provokativních názorů, demagogické argumentace, polopravd a mýtů. Alarmující byly zejména diskuzní vstupy některých učitelů, kteří sami „zevnitř profese“ zpochybňovali smysl profesního učitelského vzdělávání, dehonestovali učitelské povolání jako činnost, která nevyžaduje specializované odborné znalosti, kterou v jisté nadsázce může dělat kdokoli.

Tyto skutečnosti byly pro nás impulzem ke snaze oživit tuto diskuzi, přenést ji na stránky odborného časopisu a vybídnout tak k elaborování argumentace představitele obou názorových proudů - jak ty, kteří trvají na nutnosti kvalifikace v podobě formálního vysokoškolského vzdělání v oboru učitelství jako nutné podmínky pro kvalitní výkon profese, tak ty, kteří tuto podmínku zpochybňují. To je tedy cílem našeho příspěvku, který je upravenou a doplněnou verzí textu vyžádaného Literárními novinami pro internetovou diskuzi.

\section{Proč je nutné trvat na kvalifikaci učitelů založené na vysokoškolském magisterském studiu učitelství?}

Úvodem je třeba připomenout, že současný útok na kvalifikační požadavek plnohodnotného vysokoškolského vzdělání pro učitele je v posledních 20 letech již nekolikátým v řadě (Maňák, 1995; Spilková et al., 2004). Poprvé se objevil návrh snížit požadavky na vzdělávání učitelů 1 . stupně ZŠ na bakalářskou úroveň v roce 1995 , poté znovu kolem roku 2000, dále to byly návrhy novel zákona o pedagogických pracovnících v letech 2007 a 2009, které by umožnily působení pouze středoškolsky vzdělaných učitelů jako plně kvalifikovaných v základních školách a nakonec v roce 2011 je v Závěrečné zprávě 
Národní ekonomické rady vlády (NERV) ${ }^{3}$ navrhováno, aby se snížil zákonný požadavek na kvalifikaci pro učitele 2 . stupně ZŠ na bakalářskou úroveň (magisterské studium mělo být ponecháno pouze pro učitele 1 . stupně ZŠ a ředitele).

Tedy upřímně řečeno, zpochybňování kvalifikačních předpokladů a snaha degradovat vzdělanostní úroveň učitelů není v naší zemi bohužel „nic nového pod sluncem“. Naštěstí však nakonec dosud vždy zvítězil zdravý rozum. Pikantní je v tomto smyslu pohled do naší historie. Zhruba před sto lety probíhal zápas o prosazení vysokoškolského studia pro učitele jako nositele vzdělanosti národa. Do tohoto úsilí se zapojilo mnoho kulturních a politických osobností. Za všechny jmenujme prezidenta T. G. Masaryka, který požaduje „aby i učitel v první tř́dě měl ucelené vysokoškolské filozofické vzdělání. I když nebude filozofii učit, má filozofem být, aby byl moudrý, nezjednodušoval problémy, neuchyloval se k demagogii, měl širokou škálu fantazie a citlivě reagoval na jemné předivo utváření lidské osobnosti“ (Funda, 1995, s. 2). Tento nadčasový citát vyjadřuje podstatu požadavku na systematické, náročné a do hloubky jdoucí vzdělávání učitelů, zdůrazňuje význam celkové kultivace osobnosti v průběhu VŠ studia, roli všeobecné vzdělanosti a kulturnosti, rozvoj kritického a tvořivého myšlení, sociální komunikace, profesní etiky, pro které má univerzitní prostředí zásadní vliv.

Absurdnost zpochybňování nutnosti řádného vysokoškolského vzdělání učitelů bývá často zdůrazňována v kontrastu s jinými profesemi. Zrovna tak jako lékař bez znalosti anatomie, inženýr bez znalostí konstrukce mostu, jaderný fyzik či chemik bez znalostí fyzikálních a chemických zákonitostí, pilot, tak i učitel bez znalostí oboru, pedagogiky, psychologie, speciální pedagogiky může způsobit ve vývoji dítěti fatální škody. Slovy V. Příhody: „Je paradoxní, že ti, kteří ošetřují chrup dětem, mají úplné univerzitní vzdělání, zatímco učitelé, starající se o „duši“ dětí, se mají spokojit jen s polovysokým vzděláním..." (Příhoda, 1937, s. 149).

Pohled od naší historie směrem k současnému vývoji ve vyspělých zemích přináší podobná zjištění. V souvislosti se zvyšujícími se nároky na kvalitu školního vzdělávání prudce rostou i požadavky na práci učitele a s tím i na jeho př́ípravné i další vzdělávání. Celosvětovým trendem je snaha o výraznou pro-

3 Závěrečná zpráva podskupin Národní ekonomické rady vlády pro konkurenceschopnost a podporu podnikání. Kapitola III. - Vzdělanost (2011). Dostupné z http://www.vlada.cz/assets/ media-centrum/aktualne/NERV_kap03.pdf 
fesionalizaci učitelství i zvýšení profesionality/kvality učitelů (která jde ruku v ruce s důrazem na zvýšení kvality školního vzdělávání). Profesionalizace učitelství představuje cestu od tzv. semiprofese k opravdové profesi. Za klíčové znaky skutečných profesí (lékařs, právník aj.) jsou považovány: soubor profesních, expertních znalostí a dovedností, které výrazně odlišují profesionála od laika; dlouhá doba speciálního výcviku; smysl pro službu veřejnosti; celoživotní angažovanost a oddanost práci a klientům; etický kodex; existence profesních komor, které udržují „stavovskou“ čest a pečují o profesní etiku; kontrola nad licenčními standardy a požadavky na výkon profese; autonomie v rozhodování a odpovědnost za výkon činnosti; vysoká úroveň důvěry, autority a sociální prestiže profese, vysoký ekonomický status.

V podpoře profesionalizace učitelství je kladen důraz na široké spektrum specifických profesních, expertních znalostí - professional knowledge (Shulman, 1987; Janík, 2005), které jsou vytvářeny na základě soudobé teorie a výsledků výzkumů. Kromě kvalitně položeného základu v podobě vysokoškolského studia je zdůrazňováno celoživotní profesní učení. Jednou z priorit je teoretická reflexe praktických zkušeností, tedy přemýšlení o žácích, procesech i výsledcích učení v širších souvislostech, se snahou hlouběji porozumět pedagogickým jevům, hledat alternativní řešení apod. Činnost učitele by měla být podložená profesními znalostmi, být promyšlená ve smyslu uvědomění si co a proč dělám, $\mathrm{k}$ jakým cílům směřuji, jak kvalitně zprostředkovávat základy poznání žákům, rozvíjet myšlení a další kvality žákovské osobnosti s ohledem na věková a individuální specifika, jak předcházet neúspěchu a naopak dosahovat maximálního rozvoje individuálních předpokladů žáků apod.

Naznačené reflektivní/přemýšlivé pojetí učitelství (Korthagen et al., 2011), vyžadující systematické profesní znalosti, je opakem intuitivního učitelství, které je často založeno na př́stupech pokus-omyl, na tzv. folk pedagogy, tedy lidové, laické pedagogice nezřídka vycházející z dojmologie, mýtů, intuitivních představ a nezdůvodněných názorů. Nezpochybňujeme, že jistě existují i mezi intuitivními typy s osobnostními předpoklady pro učitelskou profesi, ale bez řádného vzdělání, kvalitní učitelé. Zkvalitňování jejich práce a celoživotní profesní růst je však limitován.

Ř́káme-li, že klíčovým znakem profesionality/kvality učitele je soubor profesního, expertního vědění, které je základem $\mathrm{k}$ hlubšímu porozumění a kompetentnímu řešení praktických problémů a reálných výukových situací, je na místě otázka po konkrétním obsahu profesních znalostí. Všeobecně 
je uznávané pojetí L. S. Shulmana, který vymezuje sedm klíčových oblastí: znalosti předmětové/oborové; obecně pedagogické (principy a strategie výuky); znalost kurikula (programy, materiály, učebnice); oborově didaktické znalosti - (porozumění obsahu vzdělání a umění ho zprostředkovávat žákủm s ohledem na jejich individuální a věkové zvláštnosti); znalost žáků a jejich vývojových i individuálních charakteristik; znalost kontextů vzdělávání (sociokulturní kontexty - rodina, způsob řízení školy, školský systém aj.); znalost cílů, záměrů, klíčových hodnot ve vzdělávání a jejich filozofické a historické zázemí.

V našich aktuálních diskuzích o kvalifikaci a vzdělávání učitelů jsou podceňovány jak znalosti oboru (chci-li rozvíjet matematické či fyzikální myšlení u žákủ, musím mít sám jako učitel velmi dobré znalosti matematiky/fyziky), tak také oborově didaktické znalosti (umět obor samo o sobě neznamená umět ho učit).

Uvedený soubor klíčových profesních znalostí a jim odpovídající profesní dovednosti a postoje vyžadují systematické teoretické vzdělání, jak oborové, tak profesní (pedagogicko-psychologické a oborově didaktické), úzce provázané se systémem reflektivní praxe. Vysoce vzdělaní, profesně kompetentní a lidsky vyzrálí učitelé jsou na celém světě považováni za ideál, ke kterému je třeba směřovat. $V$ těchto intencích realizovaly mnohé země univerzitní vzdělání i pro učitele v oblasti předškolního vzdělávání.

Shrnujeme, že vzhledem k naší tradici by snížení kvalifikačních požadavků na učitele bylo velkým krokem zpět. Signál, že k učitelství stačí talent (byt' je důležitý, chirurg musí být také manuálně zručný) a láska k dětem, že nejsou třeba specifické odborné znalosti, že učit tedy může v podstatě "kdokoliv“, že učitelství si lze osvojit od zkušených učitelů, nápodobou, praxí, výcvikem, má z dlouhodobějšího hlediska destrukční vliv, vedl by k de-profesionalizaci učitelství. Vzhledem k vývojovým trendům ve světě bychom šli tímto už dlouhou dobu překonaným řemeslným pojetím učitelské profese zcela jasně v protisměru. 


\section{Proč nelze systematické vysokoškolské studium budoucích učitelů nahradit neformálním vzděláváním a praxí?}

Žádné (byt' kvalitní) neformální vzdělání, které je většinou fragmentární a prakticistně zaměřené, nemůže nahradit (navzdory přesvědčování některých podnikatelů na trhu se vzděláváním) fundament v podobě uceleného a systematického vysokoškolského studia daného učitelského oboru. Ani dlouholetá praxe nemůže v žádné profesi, tedy ani v učitelství, nahradit vysokoškolskou př́pravu. Dovedeme si např. představit, že by dlouholetá léčitelská praxe (byt' v individuálních př́ípadech může být stejně účinná nebo dokonce účinnější než tradiční medicínské postupy lege artis, tedy v souladu s posledními poznatky vědy) nahradila studium na lékařské fakultě?

Zdůrazňujeme, že neformální vzdělání nemůže být v žádném případě ekvivalentem formálního vzdělání učitelů. Souhlasíme s názory z webové diskuze vysokoškolského učitele T. Janíka a středoškolského učitele J. Soukala, že by byla zpochybněna legitimita působení učitele, pokud by „jako reprezentant formálního (školního) vzdělávání sám příslušné formální vzdělání postrádal“. Někteří učitelé, diskutující na webu, jdou ještě dál, když ř́kají, že „učitel, který není ochoten získat předepsané vzdělání na pozici, kterou zastává, nemá morální právo po svých žácích požadovat odpovědný přístup k plnění školních povinností". I k tomuto názoru se přikláníme. Současně říkáme, že různé podoby neformálního vzdělávání a učení se z praktických zkušeností mohou úspěšně plnit (a také už plní) svou roli v procesu dalšího vzdělávání učitelů v praxi a v systému podpory jejich celoživotního profesního rozvoje.

\section{Jak řešit současnou situaci?}

Souhlasíme s názorem T. Feřteka $\mathrm{z}$ internetové diskuze, že klíčem $\mathrm{k}$ řešení problému je „Všechna uvažovaná opatření posuzovat z hlediska, zda opravdu prospějí učitelské profesi a především dětem, žákům a studentům". Chcemeli zvýšit kvalitu a profesionalitu učitelů, posílit prestiž učitelství, přitáhnout $\mathrm{k}$ této profesi kvalitní uchazeče, pak nelze připustit plošné snižování kvalifikačních požadavků. To by se v delší časové perspektivě vymstilo. K podobnému závěru dojdeme, díváme-li se na problém z perspektivy žáka a jeho rozvoje. Žáci si zaslouží kvalitní, vzdělané a stále se vzdělávající učitele, motivované a vnitřně zaujaté pro učitelskou práci, s chutí na sobě pracovat.

Učitelství je náročná profese, jejíž kvalitní vykonávání vyžaduje mnoho specifických profesních znalostí a dovedností, které se všude ve světě získávají 
systematickým vysokoškolským vzděláváním. Vysokoškolský diplom však sám o sobě ( $\mathrm{v}$ žádném oboru) nezaručuje kvalitní vykonávání profese. Formální kvalifikace je základní podmínkou a nutným základem, který musí být dále rozvíjen celoživotním vzděláváním. Připustit další působení nekvalifikovaných učitelů, zde mám na mysli zejména středoškolsky vzdělaných, $\mathrm{v}$ učitelské profesi (jde zejména o učitele 1 . stupně ZŠ, ale nejen o ně) by bylo hazardováním s kvalitou vzdělání české populace v př́šsích letech. Za velmi problematický považujeme návrh svěřit rozhodování o kvalifikaci učitele do rukou ředitele či nějakých „prověrkových“ komisí. Takové řešení lze snad dočasně, podmíněně připustit ve výjimečných případech, např. u školy, kde je tak vysoká nekvalifikovanost učitelů, že „nekompromisní př́stup by mohl vést ke kolapsu školy.

Specifickou skupinou, které je zřejmě zapotřebí vyjít vstříc, jsou absolventi VŠ, kterým chybí profesní vzdělání, tedy pedagogicko-psychologické a oborově didaktické, ale mají delší praxi, jsou motivovaní pro učitelství a mají dobré výsledky práce se žáky. Těmto učitelům je třeba vytvořit dostatečnou nabídku takových forem vzdělání, které zohlední jejich potřeby a umožní jim doplnit si vzdělání ve zkráceném časovém horizontu.

\section{Jaký je aktuální stav řešení problému nekvalifikovaných učitelů?}

Na konci května 2014 byl do Poslanecké sněmovny přeložen Vládní návrh novely zákona č. 563/2004 Sb., který upravuje předpoklady pro výkon činnosti pedagogických pracovníků. Novela umožní vykonávat př́mou pedagogickou činnost po 1. lednu 2015 vybraným skupinám pedagogických pracovníků bez odborné kvalifikace. Návrh dává řediteli školy pravomoc „písemně uznat předpoklad odborné kvalifikace" u pracovníka pracujícího na základní či střední škole na částečný úvazek (max. poloviční), který je „výkonným umělcem, výtvarným umělcem, uznávaným odborníkem v oboru“ (pro výuku předmětu odpovídajícího uměleckého nebo odborného zaměření), či trenérem. Výjimka z požadavku odborné kvalifikace se týká také výuky cizích jazyků. „Pedagogický pracovník, pro kterého je př́íslušný cizí jazyk rodným jazykem nebo který jej ovládá na úrovni rodného jazyka, splňuje předpoklad odborné kvalifikace pro výuku konverzace v tomto cizím jazyce, získal-li alespoň střední vzdělání s maturitou, nebo pro výuku tohoto cizího jazyka, získal-li vysokoškolské vzdělání“ (s. 3). Další „hájenou“ skupinou jsou učitelé, kteří dosáhnou k 1.1. 2015 alespoň 55 let věku a 20 let př́mé pedagogické činnosti. Novela umožní školám zaměstnávat nekvalifikované pedagogické 
pracovníky, pokud prokáží, že nemohou zajistit výchovu a vzdělávání pracovníkem s odbornou kvalifikací.

Dá se předpokládat, že návrh novely vyvolá kritiku. Mnohé formulace jsou vágní a umožňují různorodý výklad. Např́íklad: jak chápat nově zavedenou kategorii „uznávaný odborník“, jak se to bude prokazovat; co to znamená, že učitel ovládá cizí jazyk na úrovni rodného jazyka (kdo a jak to bude posuzovat); jak bude ředitel prokazovat, že nemohl pedagogickou činnost zajistit pracovníkem s odbornou kvalifikací; proč pro nižší úvazek kvalifikaci učitel mít nemusí a pro vyšší ano, co, když si rozšíří úvazek nad 0,5 - ztratí kvalifikaci?) Snad nejzávažnější problém a riziko spočívá v přenesení odpovědnosti za kvalitu učitelů a jejich kvalifikovanost ze strany státu a institucí připravujících učitele (garance Akreditační komise ČR) na ředitele škol.

\section{A co dál, $\mathrm{v}$ delším časovém horizontu?}

Aktuální potřeba řešit otázku nekvalifikovaných učitelů (ale kvalifikovaným, kompetentním způsobem) by neměla odvést pozornost od nutnosti řešit tento problém komplexněji, v širších souvislostech a z hlediska perspektivy. Zejména jde o vytváření podmínek a zabezpečení učitelské profese (celkové podfinancování, nezájem mladých a schopných lidí o učitelství, nedostatek motivace pro profesní růst v podobě finančního ocenění kvalitních učitelů, stárnutí učitelských sborů, absence systematické podpory profesního rozvoje učitelů - např péče o začínající učitele, mentoring). Chybí profesní standard definující kvalitní vykonávání učitelské profese v kontextu současných požadavků na školní vzdělávání. Dále jde o otázky kvality př́ípravného i dalšího vzdělávání učitelů.

Vzhledem k mnohaletému zanedbávání daných témat půjde o proces dlouhodobý, který bude vyžadovat intenzivní spolupráci všech zainteresovaných, zejména reprezentantů vzdělávací politiky, fakult připravujících učitele, školské praxe a profesních asociací. Fakulty připravující učitele jsou připraveny ke spolupráci. Je třeba začít formulováním profesního standardu - kdo je to kvalitní učitel, jakými klíčovými profesními kompetencemi má být vybaven, jak má vypadat příprava učitelů, co je jejím jádrem, jak motivovat učitele ke zkvalitňování práce se žáky, jak je podporovat v celoživotním profesním rozvoji a dalším vzdělávání apod. Profesní standard by měl být východiskem $\mathrm{k}$ rámcovému profilu absolventa a tím i $\mathrm{k}$ formulování kurikula učitelského studia. Stávající návrh profesního standardu a kariérního systému z dílny NIDV je velmi problematický, považujeme ho za promarněnou šanci. 
K situaci fakult připravujících učitele (zejména pedagogických fakult) je třeba říct, že podmínky, které jsou nastaveny pro jejich existenci, nejsou dobré (jsou nesrovnatelné s podmínkami, které mají např. mnohé neziskové organizace, které operují na trhu se vzděláváním). Jde především o chronické podfinancování (nízké koeficienty financování učitelských programů), které tlačí fakulty $\mathrm{k}$ výuce ve velkých skupinách studentů, limitují množství pedagogické praxe studentů na školách (učitelé dostávají za vedení studentů na praxi směšnou odměnu) apod. Problémem jsou také kritéria hodnocení fakult a VŠ učitelů (hodnotí se vědecko-výzkumná činnost, počet grantů, publikací, kvalifikační struktura VŠ učitelů apod., ale např. pro pedagogické fakulty specifické autorské dílo - učebnice pro základní či střední školu, byt' je třeba založena na teorii a výzkumu, nezískává žádné „body“ a tedy ani finanční prostředky pro instituci).

Z hlediska koncepce studia učitelství bylo velkou komplikací pro fakulty, že byly donuceny ke strukturování programů na bakalářský a magisterský. Velké množství času a energie bylo vyplýtváno na úpravy formy studia namísto zásadnější proměny celkové koncepce a obsahu studia. Strukturované studium učitelství přes zvýšený objem práce pro studenta i učitele (např. dvoje přijímačky a státní zkoušky, dvě kvalifikační práce) nepřineslo zvýšení kvality př́pravy studentů, spíše naopak. Jako př́íklad extrémně negativního vlivu vnuceného strukturovaného studia na kvalitu př́pravy bylo zrušení tzv. klinického roku (klinické praxe v podmínkách intenzivní spolupráce fakulty a základních škol), který byl vysoce ceněný jak akademickou obcí, tak školskou praxí. $\mathrm{V}$ nových podmínkách se klinický rok do studijního programu „nevešel“.

Na fakultách je značný inovativní potenciál, který, dostane-li podmínky, mưže okamžitě nabídnout spoustu kvalitních forem výuky. Mnohé bylo ověřeno v rámci různých rozvojových projektů či výzkumných záměrů, ale k implementaci v širším měřítku chybějí finance a další nutné podmínky. Je smutné, kolik peněz se ve školství nesmyslně vyházelo v rámci evropských projektů, jejichž samotná režie spotřebovala mnohdy značnou část prostředků. Po jejich dokončení končí i dané aktivity, tzv. udržitelnost výsledků projektu bývá nízká. Kdyby alespoň část těchto prostředků byla využita v rámci institucí, které nesou hlavní odpovědnost za vzdělávání učitelů, mohli jsme být v procesu transformace př́ípravy učitelů už podstatně dál. 


\section{Literatura}

Funda, O. A. (1995). Učitelovo sebevzdělávání. Pedagogika, 46(1), 2-14.

Janík, T. (2005). Znalost jako klíčová kategorie učitelského vzdělávání. Brno: Paido.

Korthagen, F. A. J., Kessels, J., Koster, B., \& Lagerwerf, B. \& Wubbels, T. (2011). Jak spojit praxi s teorií: Didaktika realistického vzdělávání učitelů. Brno: Paido.

Maňák, J. (1995). Hlavní otázky profesionální př́ípravy učitelů. In Teorie v pedagogické praxi, praxe v pedagogické teorii v učitelském studiu (s. 24-27). Brno: Paido.

Příhoda, V. (1937). Vědecká př́prava učitelstva. Praha: Dědictví Komenského

Shulman, L. S. (1987). Knowledge and teaching: Foundations of the new reform. Harvard Educational Review, 57(1), 1-22.

Spilková, V. et al. (2004). Současné proměny vzdělávání učitelů. Brno: Paido.

Závěrečná zpráva podskupin Národní ekonomické rady vlády pro konkurenceschopnost a podporu podnikání. Kapitola III. - Vzdělanost (2011). Dostupné z http://www.vlada.cz/assets/ media-centrum/aktualne/NERV_kap03.pdf

\section{Autoři}

Prof. PhDr. Vladimíra Spilková, CSc., Univerzita Karlova v Praze, Pedagogická fakulta, Katedra primární pedagogiky, M. Rettigové 4, Praha 116 39, e-mail: vladimira.spilkova@pedf.cuni.cz

doc. PaedDr. Radka Wildová, CSc., Univerzita Karlova v Praze, Pedagogická fakulta, M. Rettigové 4, Praha 116 39, e-mail: radka.wildova@pedf.cuni.cz

Stöckelová T., \& Abu Ghosh Y. (Eds.). (2013). Etnografie. Improvizace v teorii a terénní praxi. Praha: SLON.

Kniha představuje etnografii jako komplexní metodologicko-teoretický př́stup ke skutečnosti. Na rozdíl od většiny sociálně-vědních metodologií, nepovažuje etnografie problémy, s nimiž se výzkumníci a výzkumnice v terénu setkávají, za překážky, ale naopak za možný zdroj a prostředek poznávání. Nesourodost a mnohoznačnost skutečnosti, její neurčitosti, paradoxy a protiklady tvoří nedílnou součást pole zkoumání a žádají si tvůrčí přístupy k psaní a žánrovým formám reprezentace. Východiskem etnografické práce musí být všestranná otevřenost k experimentování. Kniha nabízí panorama metodologických kauz, které zvou čtenáře do výzkumnické „kuchyně“, kde se zvažují, míchají, pečou a někdy i připálí ingredience etnografického vědění. Autorky a autoři kombinují príběhy s teoretickou reflexí a v jednotlivých kapitolách pojednávají specifické „problémy“, se kterými se vyrovnávali při práci v terénu, analýze a psaní textů. Kde a kdy začíná a končí terénní výzkumu? Jak vypadá etnografický experiment? K čemu nás využívají ti, které zkoumáme? Jak vytvářet reflexivní vědění a vyhnout se přitom sebestřednosti? Kdy a proč podléháme autocenzuře? 